\title{
КОАГУЛЯЦЙНИЙ ПОТЕНЦІАЛ КРОВІ У ХВОРИХ НА ХРОНІЧНЕ ОБСТРУКТИВНЕ ЗАХВОРЮВАННЯ ЛЕГЕНЬ ПРОФЕСІЙНОЇ ЕТІОЛОГІЇ РІЗНОГО СТУПЕНЯ ТЯЖКОСТІ
}

Вступ. Важливе місце серед захворювань дихальної системи займає хронічне обструктивне захворювання легень (ХОЗЛ) професійної етіології, яке супроводжується змінами не лише в респіраторному тракті, але і в системі гемостазу.

Мета дослідження - оцінити систему згортання крові за перебігу ХОЗл профресійної етіології різного ступеня тяжкості.

Методи дослідження. Проаналізовано результати досліджень капілярної та венозної крові 112 працівників гірничодобувної промисловості, хворих на ХОзл різного ступеня тяжкості. Серед пацієнтів 34 особи мали I стадію захворювання, 40 осіб - II стадію, 38 осіб - III стадію, 29 практично здорових осіб становили контрольну групу. Стан системи гемостазу оцінювали за такими параметрами, як: кількість тромбоцитів, концентрація фрібриногену, рівні активованого часткового тромбопластинового часу, тромбінового часу, міжнародного нормалізованого відношення, протромбінового індексу, протромбінового відношення.

Результати й обговорення. Аналіз показників протромбінового профрілю показав, що у хворих на ХОЗЛ II-III стадій переважно змінювались рівні фракторів коагуляційного каскаду, що свідчило про порушення у зовнішній ланці системи згортання крові. У міру збільшення тяжкості перебігу ХОзл профресійної етіології зміни рівнів фракторів коагуляційного каскаду вказували на порушення системи гемостазу в бік гіперкоагуляції та депресії фрібринолітичного потенціалу крові.

Висновки. За перебігу ХОЗЛ профресійної етіології відбуваються порушення в коагуляційній ланці гемостазу в бік гіперкоагуляції разом зі збільшенням тяжкості захворювання. Порушення в згортувальній ланці гемостазу у хворих на ХОзЛ професійної етіології відзначають в основному по зовнішньому шляху згортання крові.

КЛЮЧОВІ СЛОВА: хронічне обструктивне захворювання легень; професійна етіологія; гемостаз; коагуляція.

ВСТУП. Легеням належить важлива роль у підтримці фрізіологічної рівноваги системи згортання крові й сталості фрібринолітичної активності, оскільки в нормі легенева тканина містить велику кількість прокоагулянтів та антикоагулянтів $[1,2]$. Захворювання органів дихання, зокрема хронічне обструктивне захворювання легень (ХОЗЛ) профресійної етіології, часто поєднуються з патологією гемостазу [3, 4]. Фактори системи гемостазу є реактантами гострої фрази запалення. Тому запальні реакції, що розвиваються в легенях, можуть викликати дисбаланс у системі гемостазу $[5,6]$. Для ХОЗЛ характерними $€$ реологічні та агрегаційні порушення. Вони відображають вплив гіпоксії на мембрани клітин крові $[7,8]$. Уже на ранніх стадіях перебігу хво(с) В. В. Івчук, Т. Ю. Коптєва, Т. А. Ковальчук, 2018. роби розвиваються системні порушення судинно-тромбоцитарної та фрібринолітичної ланок гемостазу з виснаженням антикоагулянтного резерву $[9,10]$. Даних щодо досліджень стану системи згортання крові й сталості фрібринолітичної активності за перебігу ХОЗЛ професійної етіології дуже мало, що і визначило нашу зацікавленість цим питанням.

Мета дослідження - оцінити систему згортання крові за перебігу ХОЗЛ профресійної етіології різного ступеня тяжкості.

МЕТОДИ ДОСЛІДЖЕННЯ. Проаналізовано результати досліджень капілярної та венозної крові 112 працівників гірничодобувної промисловості, хворих на ХОЗЛ різного ступеня тяжкості. Діагноз ХОЗЛ було встановлено на підста- 
ві міжнародних критеріїв GOLD та наказу MO3 України від 27 червня 2013 р. № 555 “Про затвердження та впровадження медико-технологічних документів зі стандартизації медичної допомоги при хронічному обструктивному захворюванні легень". Середній вік хворих чоловічої статі склав $(59,2 \pm 3,7)$ року. Серед пацієнтів 34 особи мали I стадію захворювання (ХОЗЛ I), 40 осіб - II стадію (ХОЗЛ II), 38 осіб - III стадію (ХОЗЛ III), 29 практично здорових осіб становили контрольну групу (КГ). Стан системи гемостазу оцінювали за такими параметрами, як: кількість тромбоцитів, концентрація фрібриногену (ФГ), рівні активованого часткового тромбопластинового часу (АЧТЧ), тромбінового часу (ТЧ), міжнародного нормалізованого відношення (МНB), протромбінового індексу (ПІ), протромбінового відношення (ПВ). Гемостаз досліджували з використанням наборів реактивів фрірми "Технологія-стандарт” (Росія). Забір венозної крові проводили за стандартною методикою із застосуванням 3,8 \% розчину цитрату натрію.

Статистичну обробку отриманих даних проводили методами варіаційної статистики з використанням пакетів прикладних програм Microsoft Office Excel i STATISTICA 6.0 за допомогою t-критерію Стьюдента. Дані представлено у вигляді середнього значення (М) і стандартної похибки середнього (m). Результати вважали статистично достовірними при значенні р<0,05.

РЕЗУЛЬТАТИ Й ОБГОВОРЕННЯ. ПРИ ХОЗЛ I-III стадій показник АЧТЧ, який відповідає інтенсивності тромбогенезу за внутрішнім механізмом згортання крові, суттєво не відрізнявся від значень контрольної групи (табл.).

Тест на визначення ТЧ, що характеризує кінцевий етап процесу згортання - перетворення фрібриногену у фрібрин під дією тромбіну, не показав статистично значущих відмінностей порівняно з групою контролю.
Рівень МНВ характеризує стан системи коагуляції і зовнішній шлях згортання крові та $€$ стандартом ефективності згортувальної системи крові. Він достовірно знизився у групах пацієнтів 3 II і III стадіями перебігу захворювання.

Достовірне зростання рівня ПІ у всіх трьох групах хворих на ХОЗЛ профресійної етіології свідчило про гіперкоагуляцію на рівні зовнішнього шляху згортання крові. Крім того, значення цього показника найбільш суттєво підвищувались при ХОЗЛ III порівняно як з контрольною групою, так і з групами ХОЗЛ I та ХОЗЛ II.

На зовнішній шлях коагуляційного каскаду також вказувало порушення ПВ. Так, статистично значущим було зниження ПВ за перебігу ХОЗЛ II і ХОЗЛ III профресійної етіології порівняно $з$ контрольною групою та пацієнтами з І стадією хвороби.

Фібриноген суттєво впливає на в'язкість плазми, бере участь в адгезії клітин та агрегації тромбоцитів. У свою чергу, кількість тромбоцитів може впливати на коагуляційні властивості крові. Результати коагулограми хворих на ХОЗЛ професійної етіології не виявили достовірних відмінностей серед даних показників.

Таким чином, аналіз показників протромбінового профрілю показав, що у хворих на ХОЗЛ II-III стадій переважно змінювались рівні фракторів коагуляційного каскаду, що свідчило про порушення у зовнішній ланці системи згортання крові. Зниження рівня МНB, тоді як значення ТЧ перебували в межах контролю, у хворих на ХОЗЛ II-III стадій, імовірно, мало запальне підґрунтя. Можна припустити, що запальні реакції, характерні для ХОЗЛ, призводили до зсувів у системі згортання крові в бік гіперкоагуляції. Дані зміни відбувалися за рахунок впливу на фрактори системи гемостазу, які мали значення для реакцій запалення. Отже, в міру збільшення тяжкості перебігу ХОЗЛ просресійної етіології зміни рівнів ПІ, ПВ та МНВ вказували

Таблиця - Показники згортувальної ланки системи гемостазу хворих

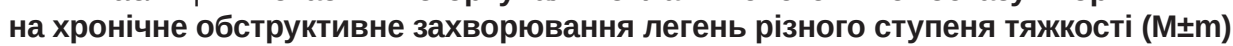

\begin{tabular}{|c|c|c|c|c|}
\hline Показник & $\begin{array}{c}\mathrm{K} \Gamma \\
(\mathrm{n}=29)\end{array}$ & $\begin{array}{c}\text { ХОЗЛ I } \\
(n=34)\end{array}$ & $\begin{array}{c}\text { ХОЗЛ II } \\
(n=40)\end{array}$ & $\begin{array}{c}\text { ХОЗЛ III } \\
(n=38)\end{array}$ \\
\hline АЧТЧ, c & $25,80 \pm 2,31$ & $23,90 \pm 2,94$ & $24,50 \pm 3,19$ & $24,70 \pm 2,86$ \\
\hline TU, c & $16,50 \pm 1,13$ & $16,80 \pm 1,21$ & $17,10 \pm 1,16$ & $17,30 \pm 1,35$ \\
\hline MHB & $1,02 \pm 0,08$ & $0,91 \pm 0,03$ & $0,86 \pm 0,05^{\star}$ & $0,84 \pm 0,02^{*}$ \\
\hline ПІ, \% & $81,70 \pm 2,68$ & $95,10 \pm 2,26^{*}$ & $101,00 \pm 3,17^{*}$ & $119,30 \pm 3,89^{* \# \wedge}$ \\
\hline$\overline{\Pi B}$ & $1,10 \pm 0,07$ & $1,12 \pm 0,03$ & $0,91 \pm 0,06^{\star \#}$ & $0,87 \pm 0,02^{\star \#}$ \\
\hline ФГ, г/л & $2,90 \pm 0,72$ & $3,10 \pm 0,31$ & $3,20 \pm 0,55$ & $3,00 \pm 0,26$ \\
\hline Тромбоцити, 10\%/л & $228,59 \pm 32,60$ & $231,27 \pm 33,14$ & $238,51 \pm 31,91$ & $239,26 \pm 32,97$ \\
\hline
\end{tabular}

Примітки:

1. * - різниця вірогідна порівняно з контрольною групою $(p<0,05)$.

2. \# - різниця вірогідна порівняно $з$ групою ХОЗЛ I $(p<0,05)$.

3. ^ - різниця вірогідна порівняно з групою ХОЗЛ II $(p<0,05)$. 
на порушення системи гемостазу в бік гіперкоагуляції та депресії фрібринолітичного потенціалу крові.

ВИСНОВКИ. 1. За перебігу ХОЗЛ професійної етіології відбуваються порушення в коагуля- ційній ланці гемостазу в бік гіперкоагуляції разом зі збільшенням тяжкості захворювання.

2. Порушення в згортувальній ланці гемостазу у хворих на ХОЗЛ профресійної етіології відзначають в основному по зовнішньому шляху згортання крові.

\section{СПИСОК ЛІТЕРАТУРИ}

1. Unfavorable effects of medically indicated oral anticoagulants on survival in idiopathic pulmonary fibrosis / M. Kreuter, M. S. Wijsenbeek, M. Vasakova [et al.] // European Respiratory Journal. - 2016. - 47, No. 6. P. 1776-1784.

2. Air pollution upregulates endothelial cell procoagulant activity via ultrafine particle-induced oxidant signaling and tissue factor expression / S. J. Snow, W. Cheng, A. S. Wolberg, M. S. Carraway // Toxicological Sciences. - 2014. - 140, No. 1. - P. 83-93.

3. An in vitro analysis of the effect of acidosis on coagulation in chronic disease states - a thromboelastograph study / H. White, R. Bird, K. Sosnowski, M. Jones // Clinical Medicine. - 2016. - 16, No. 3. - P. 230-234.

4. Fruchter O. D-dimer as a prognostic biomarker for mortality in chronic obstructive pulmonary disease exacerbation / O. Fruchter, M. Yigla, M. R. Kramer // The American Journal of the Medical Sciences. -2015. -349, No. 1. - P. 29-35.

5. Prothrombotic state in patients with severe and prednisolone-dependent asthma / M. M. Sneeboer, C. J. Majoor, A. de Kievit [et al.] // Journal of Allergy and
Clinical Immunology. - 2016. - 137, No. 6. - P. 17271732.

6. Inflammation in cystic fibrosis lung disease: pathogenesis and therapy / A. M. Cantin, D. Hartl, M. W. Konstan, J. F. Chmiel // Journal of Cystic Fibrosis. - 2015. 14, No. 4. - P. 419-430.

7. Левіна О. В. Практична цінність визначення показників еритроцитарного ряду у хворих на ХОЗЛ професійної етіології / О.В.Левіна, В.В.Івчук, Р. В. Рубцов // Мир медицины и биологии. -2017. -13, № 4 (62). - C. 50-53.

8. Impaired hemorheology in exacerbations of COPD / E. Ugurlu, E. Kilic-Toprak, I. Can [et al.] // Canadian Respiratory Journal. -2017. - 88, No. 3. - P. 32-35.

9. Targeted bleeding management reduces the requirements for blood component therapy in lung transplant recipients / I. Smith, B. L. Pearse, D. J. Faulke [et al.] // Journal of Cardiothoracic and Vascular Anesthesia. - 2017. - 31, No. 2. - P. 426-433.

10. Chronic inflammatory airway diseases: the central role of the epithelium revisited / S. T. Gohy, C. Hupin, C. Pilette, M. Z. Ladjemi // Clinical \& Experimental Allergy. - 2016. - 46, No. 4. - P. 529-542.

\section{REFERENCES}

1. Kreuter, M., Wijsenbeek, M.S., Vasakova, M., Spagnolo, P., Kolb, M., Costabel, U., ... \& Maher, T.M. (2016). Unfavorable effects of medically indicated oral anticoagulants on survival in idiopathic pulmonary fibrosis. European Respiratory Journal, 47 (6), 1776-1784.

2. Snow, S.J., Cheng, W., Wolberg, A.S., \& Carraway, M.S. (2014). Air pollution upregulates endothelial cell procoagulant activity via ultrafine particle-induced oxidant signaling and tissue factor expression. Toxicological Sciences, 140 (1), 83-93.

3. White, H., Bird, R., Sosnowski, K., \& Jones, M. (2016). An in vitro analysis of the effect of acidosis on coagulation in chronic disease states - a thromboelastograph study. Clinical Medicine, 16 (3), 230-234.

4. Fruchter, O., Yigla, M., \& Kramer, M.R. (2015). D-dimer as a prognostic biomarker for mortality in chronic obstructive pulmonary disease exacerbation. The American Journal of the Medical Sciences, 349 (1), 29-35.
5. Sneeboer, M.M., Majoor, C.J., de Kievit, A., Meijers, J.C., van der Poll, T., Kamphuisen, P.W., \& Bel, E.H. (2016). Prothrombotic state in patients with severe and prednisolone-dependent asthma. Journal of Allergy and Clinical Immunology, 137(6), 1727-1732.

6. Cantin, A.M., Hartl, D., Konstan, M.W., \& Chmiel, J.F. (2015). Inflammation in cystic fibrosis lung disease: pathogenesis and therapy. Journal of Cystic Fibrosis, 14 (4), 419-430.

7. Levina, E.V., Ivchuk, V.V., \& Rubtsov, R.V. (2017). Praktychna tsinnist vyznachennia pokaznykiv erytrotsytarnoho riadu u khvorykh na HOZL profesiinoi etiolohii [The practical value of determining the erythrocyte series in patients with COPD of professional etiology]. Mir meditsiny i biologii - World of Medicine and Biology, 13 (4), (62), 50-53 [in Ukrainian].

8. Ugurlu, E., Kilic-Toprak, E., Can, I., Kilic-Erkek, O., Altinisik, G., \& Bor-Kucukatay, M. (2017). Impaired 
hemorheology in exacerbations of COPD. Canadian Respiratory Journal, 88 (3), 32-35.

9. Smith, I., Pearse, B. L., Faulke, D. J., Naidoo, R., Nicotra, L., Hopkins, P., \& Ryan, E.G. (2017). Targeted bleeding management reduces the requirements for blood component therapy in lung transplant recipients. Journal of Cardiothoracic and Vascular Anesthesia, 31 (2), 426-433.

10. Gohy, S.T., Hupin, C., Pilette, C., \& Ladjemi, M.Z. (2016). Chronic inflammatory airway diseases: the central role of the epithelium revisited. Clinical \& Experimental Allergy, 46 (4), 529-542.

В. В. Ивчук, Т. Ю. Коптева, Т. А. Ковальчук УКРАИНСКИЙ НАУЧНО-ИССЛЕДОВАТЕЛЬСКИЙ ИНСТИТУТ ПРОМЫШЛЕННОЙ МЕДИЦИНЫ МЗ УКРАИНЫ, КРИВОЙ РОГ

\section{КОАГУЛЯЦИОННЫЙ ПОТЕНЦИАЛ КРОВИ У БОЛЬНЫХ ХРОНИЧЕСКОЙ ОБСТРУКТИВНОЙ БОЛЕЗНЬЮ ЛЕГКИХ ПРОФЕССИОНАЛЬНОЙ ЭТИОЛОГИИ РАЗЛИЧНОЙ СТЕПЕНИ ТЯЖЕСТИ}

\section{Резюме}

Вступление. Важное место среди заболеваний дыхательной системы занимает хроническая обструктивная болезнь легких (ХОБЛ) профрессиональной этиологии, которая сопровождается изменениями не только в респираторном тракте, но и в системе гемостаза.

Цель исследования - оценить систему свертывания крови при течении ХОБЛ профессиональной этиологии различной степени тяжести.

Методы исследования. Проанализированы результаты исследований капиллярной и венозной крови 112 работников горнодобывающей промышленности, больных ХОБЛ различной степени тяжести. Среди пациентов 34 человека имели I стадию заболевания, 40 человек - II стадию, 38 человек - III стадию, 29 практически здоровых лиц составили контрольную группу. Состояние системы гемостаза оценивали по таким параметрам, как: количество тромбоцитов, концентрация фрибриногена, уровни активированного частичного тромбопластинового времени, тромбинового времени, международного нормализованного отношения, протромбинового индекса, протромбинового отношения.

Результаты и обсуждение. Анализ показателей протромбинового профриля показал, что у больных ХОБЛ II-III стадий преимущественно менялись уровни фракторов коагуляционного каскада, что свидетельствовало о нарушении во внешнем звене системы свертывания крови. По мере увеличения тяжести течения ХОБЛ профрессиональной этиологии изменения уровней фракторов коагуляционного каскада указывали на нарушения системы гемостаза в сторону гиперкоагуляции и депрессии фрибринолитического потенциала крови.

Выводы. При течении ХОБЛ профрессиональной этиологии происходят нарушения в коагуляционном звене гемостаза в сторону гиперкоагуляции вместе с увеличением тяжести заболевания. Нарушения в свертывающем звене гемостаза у больных ХОБЛ профессиональной этиологии отмечают в основном по внешнему пути свертывания крови.

КЛЮЧЕВЫЕ СЛОВА: хроническая обструктивная болезнь легких; профессиональная этиология; гемостаз; коагуляция.

V. V. Ivchuk, T. Yu. Kopteva, T. A. Kovalchuk UKRAINIAN SCIENTIFIC RESEARCH INSTITUTE OF INDUSTRIAL MEDICINE, KRYVYI RIH

\section{COAGULATING POTENTIAL OF BLOOD IN PATIENTS WITH CHRONIC OBSTRUCTIVE PULMONARY DISEASE OF PROFESSIONAL ETIOLOGY OF VARIOUS SEVERITY}

\section{Summary}

Introduction. Chronic obstructive pulmonary disease (COPD) of professional etiology, which is accompanied not only by changes in the respiratory tract, but also by changes in the hemostatic system takes an important place among diseases of the respiratory system. 
The aim of the study - to evaluate the system of blood coagulation in COPD of a professional etiology of various severity.

Research Methods. The results of studies of capillary and venous blood of 112 workers of the mining industry with COPD with various severity were analyzed. Among the patients, 34 people had stage I disease, 40 people stage II, 38 people - stage III, 29 practically healthy persons made up a control group. The state of the hemostatic system was assessed by the following parameters: platelet count, fibrinogen concentration, activated partial thromboplastin time, thrombin time, international normalized ratio, prothrombin index, prothrombin ratio.

Results and Discussion. An analysis of the prothrombin profile indicates that the levels of coagulation cascade factors change in stage II-III COPD patients, which indicates a disruption in the external link of the blood coagulation system. With increasing severity of COPD of professional etiology, changes in the levels of coagulation cascade factors indicated abnormalities of the hemostatic system in the direction of hypercoagulation and depression of the fibrinolytic potential of the blood.

Conclusions. During the course of COPD of professional etiology, there are violations in the coagulation unit of hemostasis towards hypercoagulability together with an increase in the severity of the disease. Disturbance of the coagulation unit of hemostasis in patients with COPD of professional etiology occurs mainly along the external path of blood clotting.

KEY WORDS: chronic obstructive pulmonary disease; professional etiology; hemostasis; coagulation.

Отримано 17.07.18

Адреса для листування: В. В. Івчук, Український науково-дослідний інститут промислової медицини МОз України, вул. Виноградова, 40, Кривий Ріг, 50096, Україна, e-mail: ivchukv@уаhoo.com. 